\title{
ACTIVATORS OF BIOLOGICAL TRANSFORMATION AND THEIR EFFECT ON MANURE QUALITY
}

\author{
Oldrich Latal $^{1}$, Petr Novak ${ }^{2}$, Petr Sarec ${ }^{2}$ \\ ${ }^{1}$ Agrovyzkum Rapotin s.r.o., Czech Republic; \\ ${ }^{2}$ Czech University of Life Sciences Prague, Czech Republic \\ oldrich.latal@vuchs.cz,novakpetr@tf.czu.cz
}

\begin{abstract}
One of the possibilities how to improve the soil characteristics is to increase the production of highquality farmyard manure with the utilization of the agents on the basis of the organic matter biological transformation activators. The aim of this paper is to verify the agent $\mathrm{Z}$ fix efficiency from the viewpoint of the farmyard manure quality, of the barn condition parameters, mainly to decrease ammonia emissions. A total number of 90 samples of farmyard manure was collected from January to December 2017 in 2 farms (total 230 $\mathrm{LU}$, where $1 \mathrm{LU}=500 \mathrm{~kg} \mathrm{~L}$.W.; young cattle 300-500 kg live weight (in each barn) from suckler cows breeding system). Chemical parameters were tested in accredited laboratory. On each farm, the animals were stabled in 2 barns (straw bedding): the first barn with the agent $\mathrm{Z}$ fix application; the second one as control. The removal frequency of manure was 6-8 weeks. Ammonia emissions were measured in 10-day intervals (Data Logger $\mathrm{NH}_{3}$ apparatus) - measuring $25 \mathrm{~cm}$ above the bedding during 2 hours. Our results confirmed that the agent $\mathrm{Z}$ fix application $(P<0.05)$ on the straw bedding by the farmyard manure production had a positive influence on the fermentation process and the farmyard manure quality and on the microclimate in the barn. In contrast to the control, higher contents (with $\mathrm{Z}$ fix application) of the following compounds were found - $\mathrm{N}$ (by $15 \%$ ); $\mathrm{N}$ $\mathrm{NH}_{4}{ }^{+}$(by $34 \%$ ); $\mathrm{P}_{2} \mathrm{O}_{5}$ (by $42 \%$ ); $\mathrm{K}_{2} \mathrm{O}(17 \%$ ) and the $\mathrm{pH}$ value increased from 8.6 to 9.3. The decrease of the maximal mean ammonia emissions in the barn by $35 \%$ compared to the control was found. The application of the agent and its contribution to ammonia emissions and farmyard quality is in agreement with the requirements of the EU and with the Gothenburg's Protocol.
\end{abstract}

Keywords: farmyard manure, ammonia emission, barn, biological activators.

\section{Introduction}

The sufficient quantities and qualities of farmyard manure production in cattle breeding are essential to ensure the adequate soil fertility. Long-term decrease in the number of cattle bred in the Czech Republic, according to the Czech Statistical Office (2017) 1,421 thousand heads, has a negative influence on the decrease in the production of high-quality farmyard manure. Annual consumption of organic substances, applied into farm land in the Czech Republic, ranges between 4.0 and $4.5 \mathrm{t} \cdot \mathrm{ha}^{-1}$ [1]. This is covered by crop residues in the amount between 2.0 and $2.5 \mathrm{t} \cdot \mathrm{ha}^{-1}$ and the rest is necessary to be covered by farmyard manure. Recently, the application of the organic substances, originated from farmyard manure, has been only between 0.6 and $0.7 \mathrm{t} \cdot \mathrm{ha}^{-1}$ [2]. Application of the organic matter, originated from farmyard manure, has positive influence on the physical-chemical-biological parameters of the soil and its fertility [3].

One of the possibilities how to improve the soil characteristics is to increase the production of high-quality farmyard manure with utilization of the agents on the basis of the organic matter biological transformation activators. The agent Z fix utilization has a positive influence on the parameters of the barn conditions, farmyard manure quality, fermentation process optimization and ammonia production. The low-quality straw bedding and the wrong fermentation process are the main reasons of higher microbiological contamination, higher ammonia production, lower urine absorption ability and higher labour-intensity for the breeder. Jelinek et al. [4] and Brouček at al. [5] were focused on testing of the agents. In order to abate acidification, eutrophication, the Gothenburg Protocol sets levels to reduce ammonia emissions in housing systems by at least $20 \%$. Low-protein animal feeding is one of the most effective and strategic ways of reducing ammonia emission. In the suckler cow breeding system there are lower concentrations of nutrients and crude protein in the feeding rations comparing to a conventional system (with milk production), because there are different feeding techniques and nutrient requirements for different categories of animals.

Straw (litter) and its amount play an important role in farmyard production. An optimal amount of straw and its treatment is very important for the farmyard manure manipulation, its absorption of liquid manure in the barn, its optimal microbial activity during fermentation (optimal temperature and ammonia emission production), animal welfare and the total cost of a feeding day and manure production. In the Czech Republic there is a day mean amount of straw in the straw bedding between 
7.0-11.0 $\mathrm{kg} \cdot \mathrm{LU}^{-1}$. Gilhespy et al. [6] tested the amount of optimal additional straw in straw bedding for ammonia emission production in beef cattle. They found that the day value at $4.7 \mathrm{~kg} \cdot \mathrm{LU}^{-1}$ has a positive effect on the decrease of ammonia emission by $50 \%$, but not significant.

The aim of this paper is to verify the agent $Z$ fix efficiency from the viewpoint of the farmyard manure quality, of the barn condition parameters, mainly to decrease ammonia emissions.

\section{Materials and methods}

The monitoring was conducted from January to December 2017 on two representative farms (Moravian region, potato production area) with the total number of $230 \mathrm{LU}$ (1 LU $=500 \mathrm{~kg} \mathrm{L.W.)}$; young cattle (300-500 kg live weight) bred in the suckler cow breeding system; total monitored annual farmyard manure production of 3,200 tons.

Farm 1 - total agricultural area 981 ha (arable land 325 ha, grassland 656 ha), the main crops cereals, maize, alfalfa. Livestock production - total 396 LU suckler cows rearing system $(50 \%$ cross meat breeds); young cattle - $130 \mathrm{LU}$ (monitored). Housing system - straw bedding only (year-round young cattle rearing - fed in TMR; cows with calves winter only, summer grazing; herd turnover closed). The annual average production of $4.900 \mathrm{t}$ of farmyard manure.

Farm 2 - total agricultural area 480 ha (arable land 40 ha, grassland 440 ha), the main crops cereals, maize. Livestock production - total $250 \mathrm{LU}$ suckler cows rearing system (50\% cross meat breeds); young cattle - $100 \mathrm{LU}$ (monitored). Housing system - straw bedding only (year-round young cattle rearing - fed in TMR; cows with calves' winter only, summer grazing; herd turnover - closed). The annual average production of $2.500 \mathrm{t}$ of farmyard manure.

Animals on both farms were fed a total mixed ration consisted of $70-80 \%$ roughage (big bale grass silage, maize silage and hay) and 20-30\% concentrate (wheat, barley and minerals) all on dry matter basis, according to the Feeding Standards for young cattle [7]. A total 10 feed samples were analysed of each farm during the monitoring period for crude protein determination in the laboratory according to the Kjeldahl method (Kjeltec type 2200).

The young cattle (300-500 kg live weight) were stabled in 2 barns on each farm (straw bedding), with the farmyard manure removal frequency of 6-8 weeks. The agent Z fix (PRP Technologies Comp. France) is based on the calcium carbonate, magnesium carbonate, "Mineral Inducer Process" on constituent trace elements and the essential oils. All 2 barns on each farm are made from lightweight structure with natural ventilation and open spaces (windows), which can be manually controlled (reduced) with using the roller shutter during bad weather conditions. The weekly agent application $\left(1 \mathrm{~kg} \cdot \mathrm{LU}^{-1}\right)$ was conducted continually to the bedding in the first barn during the whole time of our monitoring [8], the second barn was used as the control. After drying and milling, the 90 collected samples of farmyard manure were analysed in the accredited laboratory, according to the methods of the Central Institute for Supervising $[9 ; 10]$.

Measurements of the temperature and ammonia emissions were conducted on each barn in 10-day intervals in the height of $25 \mathrm{~cm}$ above the bedding, simultaneously with the manure samplings from five points on each barn during 2 hours (per 1 point). Measurements of the ammonia emissions were carried out using the apparatus Data Logger $\mathrm{NH}_{3}$ (Comp. Bauer Technics Ltd. Czech Republic; $\mathrm{NH}_{3}$ value $0-100 \mathrm{ppm} \pm 0.1 \mathrm{ppm}$; temperature value $0-200{ }^{\circ} \mathrm{C} \pm 0.1^{\circ} \mathrm{C}$ ).

The estimated parameters were: concentrations of $\mathrm{N}_{\mathrm{tot}}\left(\mathrm{kg} \cdot \mathrm{t}^{-1}\right), \mathrm{N}-\mathrm{NH}_{4}{ }^{+}\left(\mathrm{kg} \cdot \mathrm{t}^{-1}\right), \mathrm{P}_{2} \mathrm{O}_{5}\left(\mathrm{~kg} \cdot \mathrm{t}^{-1}\right)$, $\mathrm{K}_{2} \mathrm{O}\left(\mathrm{kg} \cdot \mathrm{t}^{-1}\right), \mathrm{pH}$, ammonia emission (mean of maximum $\mathrm{ppm}$ value) and maximal temperature (mean of maximum ${ }^{\circ} \mathrm{C}$ ) of bedding by fermentation in the barn, total day consumption of straw $\left(\mathrm{kg} \cdot \mathrm{LU}^{-1}\right)$, the amount of the available $\mathrm{N}_{\mathrm{tot}}\left(\mathrm{kg} \cdot \mathrm{t}^{-1}\right.$ and EUR $\cdot \mathrm{t}^{-1}$ of farmyard manure production) were determined according to the certified methodology [8]. The data were subsequently analysed (level of significance $P<0.05$ ) with utilization of software Microsoft Excel (MS Corp., USA) and software R (RFoundation for Statistical Computing, Austria) for the whole period of our monitoring.

\section{Results and discussion}

The mean of chemical analyses and differences of the tested samples of the farmyard manure (with application of agent Z fix and control) are displayed in Table 1. Klír et al. [11] reported similar results in straw bedding (without application of the agent) in cattle from suckler cow system rearing, 
who found the mean content of $\mathrm{N}_{\text {tot }}$ by $6.0 \mathrm{~kg} \cdot \mathrm{t}^{-1}$, the mean content of $\mathrm{P}_{2} \mathrm{O}_{5}$ by $3.1 \mathrm{~kg} \cdot \mathrm{t}^{-1}$ and the higher mean content of $\mathrm{K}_{2} \mathrm{O}$ by $10.7 \mathrm{~kg} \cdot \mathrm{t}^{-1}$ in farmyard manure. The higher manure content of monitored nutrients with application of the agent $Z$ fix over the control can be justified by the chemical composition of the agent $Z$ fix and its controlled application; by the optimal amount of straw; by the controlled biological fermentation process of manure, while reducing fermentation losses (barn, dunghill) and better manure management during its storage and field application. Further, there was found the decrease of the maximal mean ammonia emissions by $35 \%$ (control: $23.2 \mathrm{ppm}$ ), the decrease of maximal mean temperature by fermentation of the farmyard manure in the barn from $43-46^{\circ} \mathrm{C}$ to $25-28^{\circ} \mathrm{C}$ and the increase of the $\mathrm{pH}$ value of the farmyard manure from 8.6 to 9.3. Differences in $\mathrm{NH}_{3}$ emissions (with the agent $\mathrm{Z}$ fix application and control in 2017; means of the 68 samples) are displayed in Figure 1. Jelinek et al. [4] found the decrease of the ammonia emissions by $24.0 \%$ by the utilization of biological activators; whereas in studies [5] it was by $25-60 \%$. Application of the agent $Z$ fix in our study proved good results by its utilization in the barns with deep bedding and it meets the requirements of the EU for the decrease of ammonia emissions in the barns at least by $20 \%$. Dewes [12] monitored the $\mathrm{pH}$ value and temperature during the manure fermentation process.

Table 1

Chemical analyses of tested samples of farmyard manure (2017)

\begin{tabular}{|c|c|c|c|c|}
\hline Parameter & $\begin{array}{l}\text { Agent } Z \text { fix } \\
\text { application }\end{array}$ & Control & Index & $P$ value \\
\hline Tested samples, n & 60 & 30 & - & - \\
\hline Dry matter, n & 23.2 & 23.3 & - & - \\
\hline $\mathrm{N}$-total, kg·t ${ }^{1}$ & 6.10 & 5.30 & 1.15 & 0.0284 \\
\hline $\mathrm{N}-\mathrm{NH}_{4}{ }^{+}, \%$ & 0.43 & 0.32 & 1.34 & - \\
\hline $\mathrm{P}_{2} \mathrm{O}_{5}, \mathrm{~kg} \cdot \mathbf{t}^{1}$ & 2.70 & 1.90 & 1.42 & 0.0423 \\
\hline $\mathrm{K}_{2} \mathrm{O}, \mathrm{kg} \cdot \mathrm{t}^{-1}$ & 6.10 & 5.20 & 1.17 & 0.0483 \\
\hline C:N ratio & $20.1: 1$ & $24.3: 1$ & 0.82 & - \\
\hline $\begin{array}{c}\mathrm{NH}_{3} \text { maximal mean } \\
\text { value, } \mathrm{ppm}\end{array}$ & 15.00 & 23.20 & 0.65 & 0.0223 \\
\hline $\begin{array}{c}T_{\max } \text { maximal mean } \\
\text { value, }{ }^{\circ} \mathrm{C}\end{array}$ & $25.00-28.00$ & $43.00-46.00$ & - & - \\
\hline
\end{tabular}

Note: $\mathrm{NH}_{3}$ [measured $25 \mathrm{~cm}$ above the bedding during 2 hours per 5 points on each barn]; Tmax [measured in the collected samples per 5 points on each barn]; Index [the proportion between Z fix application and control samples value]

A decisive environmental aspect is that animals metabolize only a small part of the feed for their production and the undigested part is eliminated in the excreta. For this reason, it is necessary to ensure that the concentrations of nutrients in the diet are recommended by the norms of nutrients for the category of animals.

In the feeding ration, there was observed the crude protein concentration between $120-130 \mathrm{~g} \cdot \mathrm{kg}^{-1}$ in dry matter. There was no highly concentrated protein in our feeding ration. Our animals were fed with the high amount of roughage (60-70 \% dry matter content of grass silage, meadow hay silage and corn silage). The same recommendations are also mentioned in [5] and [13].

A daily consumption of straw was in control treatment at level of 9.0-11.0 kg. $\mathrm{LU}^{-1}$. A daily consumption of straw decreased by up to $30 \%$ at level of $6.3-7.7 \mathrm{~kg} \cdot \mathrm{LU}^{-1}$ with the use of the agent $\mathrm{Z}$ fix application. In the agent $\mathrm{Z}$ fix application during the monitoring period (6-8 weeks) we observed improvement of welfare and cleanliness of animals, better bedding stability, decrease of the maximal mean ammonia emissions by $35 \%$ (control: $23.2 \mathrm{ppm}$ ), decrease of maximal mean temperature by fermentation of the farmyard manure in the barn from $43-46{ }^{\circ} \mathrm{C}$ to $25-28{ }^{\circ} \mathrm{C}$ and the reduction of the farmyard manure balance per year. Klír et al. [11] found that at a lower temperature during the fermentation of manure and additional application of the biological agent, there were no high losses of 
nutrients and production of ammonia emissions. Gilhespy et al. [6] found that the day value at 4.7 $\mathrm{kg} \cdot \mathrm{LU}^{-1}$ had a positive effect on the decrease of ammonia emission by $50 \%$, but not significant. Dewes [12] monitored the $\mathrm{pH}$ value, temperature and ammonia emission production during the manure fermentation process in the stable.

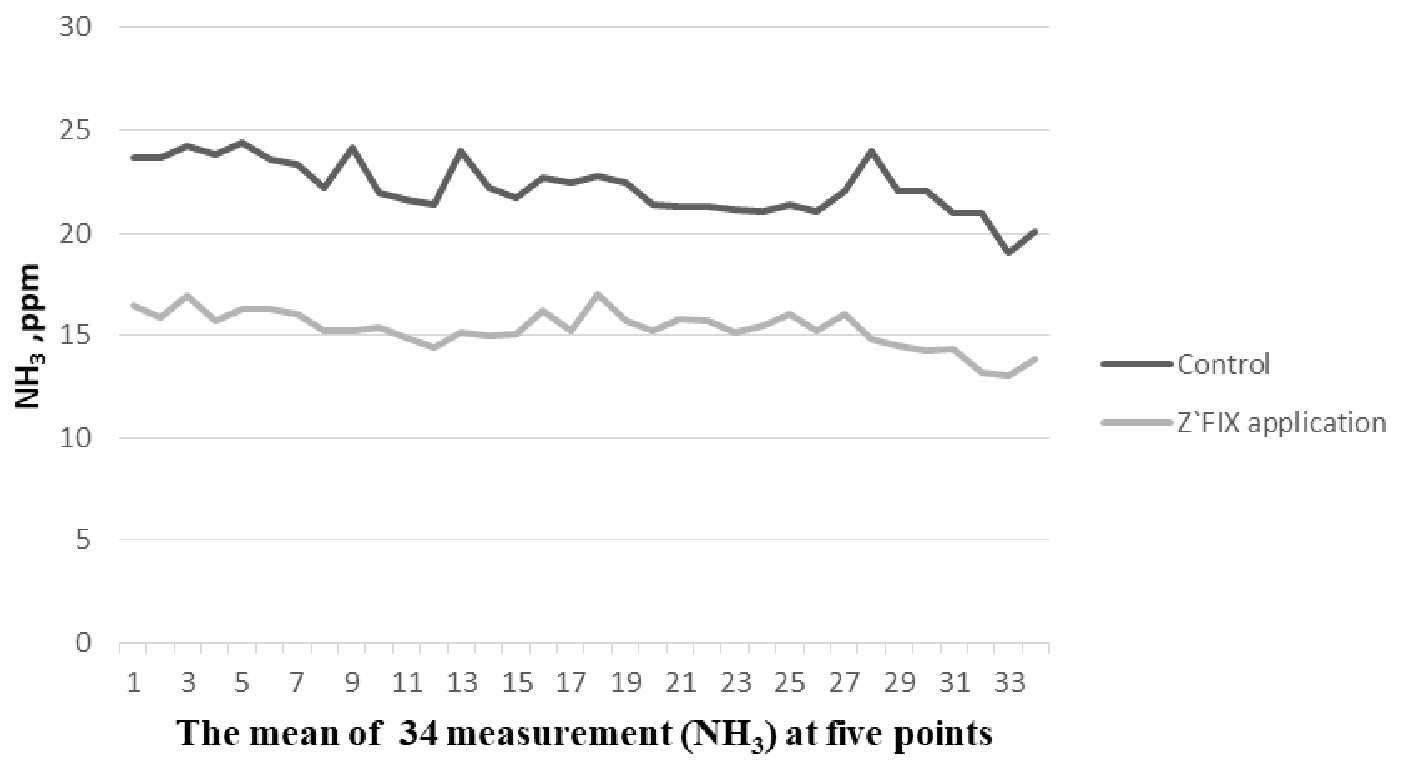

Fig. 1. Monitoring of $\mathrm{NH}_{3}$ emissions in barn (with agent $\mathrm{Z}$ fix application and control; from total 68 measured samples at five points during monitored period)

Average prices of farmyard manure are under [14] and methodological patterns [11] at the level of 16.32 EUR $t^{-1}$. The value of the farmyard manure in our experiment is at the level of $17.92 \mathrm{EUR} \cdot \mathrm{t}^{-1}$ with the agent Z'fix application and at the level of $15.70 \mathrm{EUR} \cdot \mathrm{t}^{-1}$ in control (without application). The amount of the available $\mathrm{N}_{\text {tot }}$ by its $65 \%$ utilization (on medium soils) and the agent $\mathrm{Z}$ fix application can be increased by $0.52 \mathrm{~kg} \cdot \mathrm{t}^{-1}$ of the farmyard manure. This value means (by the dose of $40 \mathrm{t} \cdot \mathrm{ha}^{-1}$ ) saving of $20.8 \mathrm{~kg}$ of N applied in the form of mineral fertilizers. When applied in the silage maize, this value represents the increase of the yield by $3.5 \mathrm{t} / \mathrm{ha}$ (at $32 \%$ dry matter). The average price of the farmyard manure treated with the agent $Z$ fix is higher by $2.2 \mathrm{EUR} \cdot \mathrm{t}^{-1}$, if we quantify the total price of the nutrients in the farmyard manure (according to the recalculation of nutrients in the basic fertilizers) in the Czech Republic in 2017.

\section{Conclusions}

1. On the basis of our findings (2017) we can conclude that the agent $Z$ fix application $(P<0.05)$ on straw bedding by the farmyard manure production had a positive influence on the fermentation process and subsequently on the farmyard manure quality and on the microclimate in the barn.

2. In contrast to the control, there was found the content of Ntot higher by $15 \%$, the content of N$\mathrm{NH}_{4}{ }^{+}$higher by $34 \%$, the content of $\mathrm{P}_{2} \mathrm{O}_{5}$ higher by $42 \%$, the content of $\mathrm{K}_{2} \mathrm{O}$ higher by $17 \%$, the decrease of ratio $\mathrm{C}: \mathrm{N}$ from $23: 1$ to $20: 1$, and the daily consumption of straw was reduced by $30 \%$ to $7.7 \mathrm{~kg} \cdot \mathrm{LU}^{-1}$.

3. The amount of the available $\mathrm{N}_{\text {tot }}$ (by its $65 \%$ utilization on medium soils) can be increased by $0.52 \mathrm{~kg} \cdot \mathrm{t}^{-1}$ of farmyard manure. The decrease of the maximal mean ammonia emissions in the barn by $35 \%$ compared to the control was found.

4. The maximal values of the temperatures by the farmyard manure fermentation in the barn decreased from $43-46{ }^{\circ} \mathrm{C}$ to $25-28{ }^{\circ} \mathrm{C}$ and the $\mathrm{pH}$ value increased from 8.6 to 9.3.

5. The utilization of the agent and its positive effects on ammonia emissions and on the other parameters is in the agreement with the requirements of the EU and with the Gothenburg's Protocol. 


\section{Acknowledgements}

This work was supported by Research Project of the Technology Agency of the Czech Republic No. TH02030169.

\section{References}

[1] Škarpa P. Soil fertility as a prerequisite for sustainable plant production. Proceeding of 31 . evaluation seminar "Tomato production system, sunflower production system". Prague: SPZO, 2014, pp. 159-163.

[2] Richter R, Hlušek J, Ryant P, Lošák, T. Organic fertilizers and their position in agricultural practice. Úroda 50 (9), 2002, pp. 9 -12 (In Czech).

[3] Samuil C, Vintu V, Iacab T, Saghin GH, Trofin A. Management of permanent grasslands in North-Eastern Romania. Grassland Science in Europe, 14, 2009, pp. 234-237.

[4] Jelinek A, Dedina M, Pliva P, Soucek J. Research of biological agent's effects on reduction of ammonia concentration in stables of intensive farm animals breeding. Research in Agricultural Engineering, 50 (2), 2004, pp. 43-53.

[5] Brouček J. Producing harmful emissions from bovine livestock and reducing it. Practical Methodology (e-book). NPPC Nitra, 2014, 18 p (In Slovak).

[6] Gilhespy SL, Webb J, Chadwick DR, Misselbrook TH, Kay R, Camp V, Retter AL, Bason A. Will additional straw bedding in buildings housing cattle and pigs reduce ammonia emissions? Biosystems Engineering, vol. 102, 2009, pp. 180-189.

[7] Sommer, A., Čerešňáková, Z., Frydrych, Z., Králík, O., Králíková, Z., Krása, A., Pajtáš, M., Petrikovič, P., Pozdíšek, J., Šimek, M., Třináctý, J., Vencl, B., Zeman, L. Nutrient demand and feeding nutrition table for ruminants. ČAZV, Animal Feeding Commission, Pohořelice, 1994, 198 $\mathrm{p}$ (In Czech)

[8] Látal O., Pozdíšek J., Štýbnarová M., Kopeček P. Improve the economy and efficiency on production of manure with the use of organic matter biological transformation activators to improve soil properties. Certified methodology. Certified by Ministry of Agriculture of Czech Republic, certificate No. 17210/2015-3. Agrovýzkum Rapotín Ltd., 2015, 46 p.

[9] Novotný F. Methods of chemical analysis for the evaluation of the quality of varieties I. Uniform working procedures. UKZUZ Brno, 2006, 28 p (In Czech).

[10]Czech Republic. Methods of sampling and laboratory testing for the official control of feedingstuffs. Commission Regulation (EC) No 152/2009.

[11] Klír J, Kunzová E, Čermák P. Framework methodology of plant nutrition and fertilization. Methodology for practice. 2nd updated edition, VÚRV v.v.i., Prague 2008, p 48 (In Czech).

[12] Dewes $\mathrm{T}$. Effect of $\mathrm{pH}$, temperature, amount of litter and storage density on ammonia emissions from stable manure. The Journal of Agricultural Science, 127, 1996, pp. 501-509.

[13] Pozdíšek J, Loučka R, Machačová, E. Digestibility and nutrition value of grass silages. Czech J. Anim. Sci., 48, 2003, pp. 359-364.

[14] Kopeček P. Methodological approach to the assessment of the economy of production of dairy cattle and combined utility type. Applied certified methodology. Agrovýzkum Rapotín, 2012, p 103 (In Czech). 